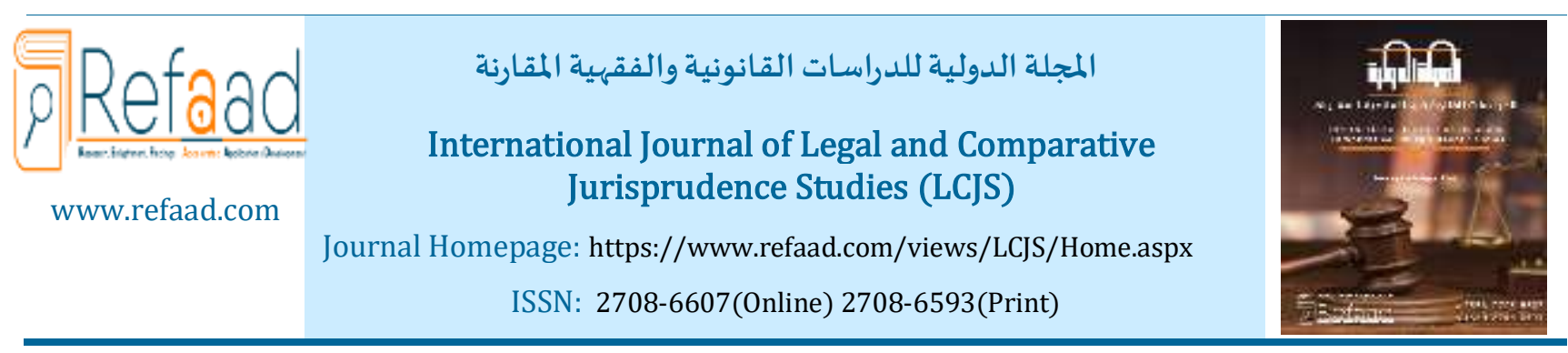

\title{
The Palestinian civil police: between force and legitimacy
}

\author{
Jihad Al-Kiswani \\ Assistance Professor of Criminal Law \\ Al-Quds University, Palestine \\ jkisswani@staff.alquds.edu
}

Fadi Rabia

Assistance Professor of Criminal Law Al-Quds University, Palestine fadee_hosnee@yahoo.com

DOI: https://doi.org/DOI:10.31559/LCJS2020.1.2.5

\begin{abstract}
This research is dedicated to look in-depth at the consequences of police partiality and Polarization in eroding police legitimacy. It argues that police deviances and human rights violation have a great influence on the Palestinian's readiness for statehood. The establishment of the Palestinian Civil Police (PCP) embraces many characteristics that have a remarkable influence on its performance up to the present. Such features include its military style, and the politicization of the police. These features have provoked a discussion on the way the PCP attempts to strike a balance between meeting the Palestinian expectation of defending their country but also to counter the so-called "terrorism" directed against Israeli occupation of the Palestinian territory. Such complexity of police function has contributed to police brutality, corruption and politicisation, which in turn, has decreased police legitimacy in the eyes of the public. As a result, the erosion of police legitimacy has become a great challenge for the efforts of police reforms.

This study suggests that legitimating authority must rely on public trust and confidence instead of force and cruelty. The PCP's legitimacy may be more secured if progress in domestic Palestinian reconciliation takes place in the future. Shifting up to a higher degree of fairness and effectiveness in policing, as well as, the integration of political opponents into the police organization would help to restore police legitimacy.

Based on governmental documents and other reports published by civil society groups, this paper provides unique insights into the context in which police legitimacy is conferred. This should be of great interest to decision makers, researchers, and international donors.
\end{abstract}

Keywords: police; Civil; legitimacy; force; Palestine.

\section{Introduction:}

The magnitude of the Israeli attacks, high rate of crimes, and incidents of civil unrest in the Occupied Palestinian territory have touched new heights. Posting major challenges to the Palestinian Civil Police (PCP). Perhaps one of the greatest problems for the PCP is not only to deal with crime but also with unprecedented political turmoil. This paper is dedicated to look in-depth at the impacts of police partiality and Polarization in eroding police legitimacy. It argues that police misconducts and human rights violation have a devastating influence on the Palestinian's readiness for statehood, which in turn, has decreased police legitimacy in the eyes of its own people. As a result, the erosion of police legitimacy has become a great challenge for police reforms.

Police legitimacy has a significant influence on reporting crimes, increasing public trust, and public cooperation with law enforcement agencies. The more citizens voluntarily comply with laws and become selfregulating, the less likely civil disturbance and violence would take place in the community ${ }^{1}$. The legitimacy of police is, in reality, central to maintaining social control and political stability. The trust and support of public provided to the police is mainly fostered when police interact positively and equally with the public ${ }^{2}$.

Although there is a wide consensus on the importance of police legitimacy in its existence and performance, there is no single, unified definition of police legitimacy. Different theories and perspectives give different dimensions of this term. The term legitimacy has been used to reflect justice, legality, and morality 3 .

Weber as a sociologist scholar is a brilliant. He inspires the modern thoughts regarding the notion of legitimacy. Weber supports the theory of legal legitimate dimension and rationalization. Legitimacy is to be viewed as a

\footnotetext{
1 Tyler, T. and Y, Heo (2002). Trust in the Law: Encouraging Public Cooperation with the Police and Courts. New York, Russell Sage Foundation. Page 251. 2 Tyler, T. R. (2004). "Enhancing Police Legitimacy." Annals of the American Academy of Political and Social Science 593: 84-99.

${ }^{3}$ Sofaer, A. (2003). The Best Defense?: Legitimacy \& Preventive Force. California, Hoover Institution Press. Page 34.
} 
supplement to legality. Accordingly, there is no need to ponder the moral justification in the applicable laws as long as they are abstract and formal, so far legitimacy is derived from legality 4

However, Kocken (2008) refuses to connect the legality with the legitimacy as that laws by itself has a moral power ${ }^{5}$. He argues that the principles as the rule of law, the impartiality of law, and the determinacy of law, are often implied in laws. These principles are merely assumptions, they lack foundation. This leads to the conclusion that legitimacy shaped by ethics and morality should not be expected to exist in any organization easily because this organization abides with laws. In other words, when the institution lacks legitimacy, legality becomes no longer valuable, To shed light on political perspective, Archibugi and Croce (2012) discuss the concept of legitimacy based on political theory and international practice. They argue that legitimacy should link to the concept of "democratic

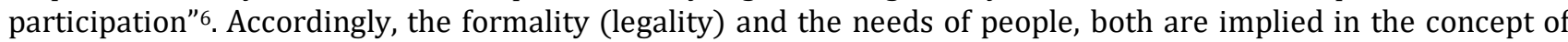
"democratic participation"7.

Furthermore, Jackson, Bradford et al. (2012) draw a line between the legitimacy of police as an institution (high-level legitimacy) and as an organization (low-level legitimacy) ${ }^{8}$. Accordingly, the legitimacy of police as an institution is associated with the existence of the police; it shapes the relationship between individuals and the social-political framework. However, the legitimacy of the police as an organization is more about practicing at the individual level, where the dissensions revolve around the police policies, its tactics, and the powers given to its officers. This standard therefore, may be useful for tracking the PCP legitimacy.

\section{Research Questions:}

This study will explore the working of police legitimacy in Palestine through testing the validity and legitimacy of the PCP functions, and examining the consequences of losing police legitimacy in the eyes of the Palestinians. The primary research questions addressed in this thesis are:

- To what extent does the PCP enjoy public trust and legitimacy in Palestine?

- What reasons that make citizens become dissatisfied and lose confidence in the PCP?

\section{Originality and Significance of the Study}

In general, academic literature provides a limited number of studies of policing in Palestine. This research is important because it is the first study that defines the problem of police legitimacy and its various dimensions within the PCP. This study contributes greatly to increase levels of consent in policing, as well as to the field of political studies in general.

It supports the strategies for community policing by systematically investigating how police law reform can play a great role in shaping police policy and operations, which in turn, can increase perceptions of police legitimacy.

The aim of this research is to serve as an appropriate resource for decision-makers by providing a detailed analysis of police legitimacy and making recommendations for reorganizing the police structure and functions to promote police legitimacy even among those who disagree with the Palestinian Authority on political matters. Furthermore, the research findings can be comparatively useful for both police scholars and outside academics and researchers in Palestine.

\section{Structure of the Research}

This study falls into two parts. The first part addresses the formation of the PCP, including its establishment and the legal framework of the organisation. The second part is dedicated to look in-depth to the legitimacy of the PCP, examining the consequences of losing the PCP legitimacy.

\section{- The Formation of the PCP}

\section{a. The establishment of the PCP}

Providing a complete picture of the Palestinian Civil Police (PCP), particularly of its establishment and functions, is not an easy task, even for experienced research workers. The establishment of the PCP was complicated

\footnotetext{
${ }^{4}$ PRABHAT, D. 2008. Examining Weber on Legal Legitimate Domination: A Case Study of the Opposition to the Patriot Act in the United States. In: LIESBETH HUPPES-CLUYSENAER, R. K., OLIVER W. LEMBCKE (ed.) Legality, Legitimacy and Modernity: Reconsidering Max Weber's Concept of Domination, NSW, Australia: Reed Business Information PTY Ltd. Page 21.

${ }^{5}$ Kocken, J. (2008). " Questioning Legitimacy or Why Social Scientists Find Legitimacy Where None Exists." Social Science Research Network (SSRN). from http://ssrn.com/abstract=1409652 or http://dx.doi.org/10.2139/ssrn.1409652. Page 11, 12.

${ }^{6}$ Archibugi, D, and Croce, M. 2012. Legality and Legitimacy of Exporting Democracy. Book: Legality and Legitimacy in Global Affairs. Oxford University Press, USA. Page 432.

7 The Authors classify various points of view of scholars based on the relation between the concepts of legitimacy and legality. These views are grouped as the following: (A) Legitimacy after Legality (Legitimacy derives from legality. Without enacting laws; there is no room for legitimacy. A high degree of formality is requested before the appearance of legitimacy), (B) Legitimacy along with Legality (Both concepts are complementary. Legal framework become legitimate when it includes basic values, needs, and interests of citizenry, meanwhile, citizenry will that provides legitimacy cannot override major legal principles and rights of individuals), (c) Legitimacy before Legality (Legality is mere by-product for legitimacy. What is legitimate is decided by the majority), (D) This conception is underlined by the authors, as illustrated above.

${ }^{8}$ Bradford, B. and J. Jackson (2011). "When Trust is Lost: The British and their Police after the Tottenham Riots." books \& ideas.net: 16. Page 37.
} 
because it was linked with the establishment of the Palestinian National Authority (PNA), which is unique but also complicated. The PNA - also known as the Palestinian Authority, or PA-arose out of Palestinian resistance movements. It has become responsible for public order and internal security and has renounced violence.

The Declaration of Principles on Interim Self-Government Arrangements (DOP) between the Palestine Liberation Organization (PLO) and the Israeli Government in September 1993 (the Oslo I Accords) aimed to peacefully bring to an end more than six decades of armed conflict between Palestinians and Arab countries from one side and Israel from the other. This was supposed to have been achieved through ending the Israeli occupation of Palestinian territory, which should have resulted in recognition of a Palestinian state living peacefully side by side with its neighbour, the state of Israel.

The PLO began building the PNA in the summer of 1994. From that time onward, it started to fill the gap created by redeployment of the occupying Israeli military by establishing both civil and military institutions. Forming the Palestinian Security Forces (PSF) was the milestone in building the institutions of self-rule (Milton-Edwards, 1997, Lia, 2006). The PCP is part of the Palestinian Security Forces (PSF). However, its establishment has some distinct features compared with other security branches.

The establishment of the PCP commenced with a presidential decree made by Yasser Arafat, as Executive President of the PNA, in June 1994. The creation of the PCP started in Gaza Strip and Jericho in order to fill the gap left by Israeli redeployment, which had been done in phases. It is worth noting that the overwhelming majority of the senior commanders were selected from the veterans who had come back from exile. In spite of the limited number of police officers who came from other factions, most selected commanders were belonged to Fatah faction.

The PCP retains many characteristics that have a major influence on its performance quality. Perhaps one of the most dominant character of the police was the military style. Like all PSF, the PCP was created to be part of the coercive security structure: all security forces are subject to the same military laws, training system, military ranks, and organizational structures, and even use the same kinds of weapons.

Although, the PCP has made huge progress in evolving to a more advanced phase in terms of its structure, law enforcement, and controlling remote areas, implementing the principles of the rule of law and human rights will continue to be problematic and challenging for the organization.

\section{b. The Legal Framework of the PCP}

In the wake of the Oslo Accords, the PNA was keen to unify the Palestinian legal system by issuing dozens of legislations affecting all aspects of Palestinian life. As a matter of principle, all laws that existed prior to the PNA remain applicable as long as they are not in conflict with new Acts9.

Generally, different legal systems have contributed to the shaping of the Palestinian legal framework. Such legal systems include: Ottoman rules, British mandate legislation, Jordanian laws, Egyptian laws, Israeli military orders, and the PNA legislation.

Khalil (2007) argues that the lack of an appropriate legal framework for the PSF could hardly be addressed fully by the Palestinian authorities, as the Oslo Agreement restrains the PLC from functioning freely ${ }^{10}$. The creation of the security sectors and the key responsibilities for their missions are explicitly defined in the Oslo II Accords, and therefore little room is left for the PLC to exercise its role in this regard. ${ }^{11} \mathrm{Further}$, although the Agreement enumerates security branches that shall be established, there is no legal prohibition against the redesigning of the structure of the PSF, as long as the maximum number of recruits or security sectors does not exceed the number agreed upon in the Accords.

Formulating a suitable legal framework for the PCP has been at the centre of both attempts to reform security and the state-building process. Thus, many efforts were made in order to address this issue ${ }^{12}$. Yet the lack of a legal framework for the PCP is still causing great impacts not merely on the PCP but also on the whole criminal justice system. The mission of the police and its structure are still not adequately defined in law. Its structure has not been improved by government, and therefore the current organizational structure could be described as unstable, vague, and chaotic.

In regard to the powers invested in "judicial" police officers, ${ }^{13}$ a normative framework is attempted in many Acts, although many deficiencies exist. Such Acts include Police Act No. 23 of 2017, the Penal Procedure Law No. 3

\footnotetext{
${ }^{9}$ Presidential Decree No. 1 in 1994, related to the recognition of all laws that had existed in 1967 including military orders enshrined by Israeli occupation, states that such legislation should remain until being repealed or replaced by the Palestinian authority.

${ }^{10}$ KHALIL, A. 2007. The Legal Framework for Palestinian Security Sector Governance. In: FRIEDRICH, R. \& LUETHOLD, A. (eds.) Entry-points to Palestinian Security Sector Reform. Geneva and Ramallah: Geneva Centre for the Democratic Control of Armed Forces. Page 107.

${ }^{11}$ In regard to the key missions of the PSF, Annex 1 of the Israeli-Palestinian Interim Agreement stipulates "maintaining internal security and public order; protecting the public and all other persons present in the area, as well as, protecting their property, and acting to provide a feeling of security, safety and stability...preventing acts of harassment and retribution; combating terrorism and violence, and preventing incitement to violence; performing any other normal police functions".

12 DCAF 2008. The Security Sector Legislation of the Palestinian National Authority, Geneva: Geneva Centre for the Democratic Control of Armed Forces (DCAF). Page 23.

13 The term "judicial officer" is used in the Penal Procedure Law No. 3 of 2001. It refers to those police officers who are responsible for investigating crimes, gathering the evidence necessary for prosecutions at trial, and enforcing the law. In other words, judicial officers are entrusted to carry out police investigative and law enforcement functions. Despite their title, they are not judges. In other systems, they would be called criminal investigators. Such officers are subject to the prosecutors' control in the exercise of the functions of their positions (see: Articles 20, 21, 22 of the Penal Procedure Law No. 3 of 2001).
} 
of 2001, the Firearms and Ammunition Law No. 2 of 1998, the Public Meeting Law No. 12 of 1998, and the Correction and Rehabilitation Centers ("Prisons") Law No. 6 of 1998.

Regarding the Police Act, the law has been subject to criticism by many civil society actors for many reasons, especially the accountability system within the PCP and how it should interact with different aspects of the criminal justice system. ${ }^{14}$ Another reason for criticism is that the exercise of preventative force by the police is not clearly defined or restricted in the law. It is left with the police officers to exercise their discretion in this matter. This could open the door to the corrupt officers and to arbitrary rule.

It may be true that most challenges the police legal system face more or less have coloration with political situation in Palestine. The failure to design an appropriate legal framework was, and still is, internal political division. As the PLC has been suspended since 2006, and consequently, the Police Act was issued by a president Mahmoud Abas, using his exceptional authority (presidential decree) to deal with such exceptional situation. Accordingly, the Police Act does not enjoy the consent of all political parties.

\section{- Facing the Question of PCP Legitimacy}

As mentioned above, there is no exact definition of police legitimacy and many scholars provide many different definitions of the term. Consequently, seeking for the availability of legitimacy is a daunting target to follow. There are no agreed yardsticks among scholars to measure legitimacy.

For the research purposes, there could be two methods to question the legitimacy of the PCP. The first method is to evaluate the legitimacy of the PCP as an institution. Such evaluation is reflected in two judgments: the PCP missions, whether or not; the missions of the police are legitimate and vital for the society. The second judgment revolves around examining the delegated authority that grants power to the PCP. These two methods should be considered the public confidence as a substance to call for legitimacy. On the other hand, the second method is more about examining the PCP legitimacy as an organization. This is to be done though the evaluation of the PCP transparency and the extent of police corruption and deviance.

\section{a. Examining the PCP Legitimacy}

As mentioned above, the examination of police legitimacy is reflected in two judgments: reviewing the legitimacy of police as an institution, and its legitimacy as an organization. From institutional perspective, the PCP legitimacy has to be decided upon the question, whether or not; the missions of the police are legitimate and vital for the society?

Many scholars have questioned the legitimacy of the PCP from different perspectives. While some of them equate the mission of the PCP with that of the occupiers, others deny the PCP's legitimacy based on the Hamas argument by Hamas, after it took over the Gaza Strip in 2006, that the PNA in the West Bank lacks legitimacy, and consequently that its police, the PCP, also lacked legitimacy.

Milton-Edwards (1997), for instance, denies a link between the PNA's performance and the authority as a legitimate government, claiming that the security branches have resorted to coercion, exactly as the occupiers did ${ }^{15}$.

It is difficult to reject such claim: The Palestinian Security Forces (including the PCP) have used excessive force to subdue its opponents, and politics has an influence on the PCP's performance ${ }^{16}$. One might ask, however, whether such factors contribute to eroding police legitimacy.

Although the nature of its performance has a tremendous impact on any institution demanding acceptance from the public, the legitimacy of an institution should not necessarily be denied because of the existence of shortcomings in its performance. The public may have reason to tolerate them. Two key elements of legitimacy are: (1) the nature of the organization's mission; and (2) the delegation of authority and power to police in order to exercise its duties.

On the one hand, the PCP mission is in accordance with the law. The Basic Law itself does not include a specific description of the security sector; however, it does state that the tasks of the PSF and PCP are limited to defending, serving, maintaining public order, and protecting the country and its citizens. Regulating further issues in detail is still to be addressed in legislation. ${ }^{17}$ This suggests that the duties required of the PCP are legitimate, by virtue of the fact that the citizens expect the PCP to fulfill its obligations toward them under the law.

On the other hand, Milton-Edwards' argument is not without merit. One must not ignore the fact that the PCP's major missions as outlined in the Oslo Accords are not merely to enforce public order and internal security, but also to counter the so-called "terrorism" directed against Israel and the Israeli occupation of Palestinian territory ${ }^{18}$. Indeed, domestic critics of the PNA have mainly dwelled on the issue of "security cooperation" with Israel ${ }^{19}$. Islamic

\footnotetext{
14 Interview numbers $(140227,140302$, and 140203) conducted with representatives of CSOs, 2014.

15 MILTON-EDWARDS, B. 1997. Policing Palestinian society. Policing and Society, Volume 7, pp 19-44.

16 See also: Lia, B. (2006). A police force without a state : A history of the Palestinian security forces in the West Bank and Gaza. Reading, Ithaca. Page 143. Luft, G. (1998). "The Palestinian Security Services: Between Police and Army." The Washington Institute. Retrieved 4/Augest/2013, 189, from http://www.washingtoninstitute.org/.

17 Article 84 of the Amended Basic Law of 2003.

${ }^{18} \mathrm{Lia}$, B. (2006). A police force without a state: A history of the Palestinian security forces in the West Bank and Gaza. Reading, Ithaca. Page 3. ${ }^{19}$ Brown, N. J. (2002). The Palestinian Reform Agenda, UNITED STATES INSTITUTE OFPEACE. No. 48: 53. Page 35.
} 
opponents have resisted the notion of Palestinian self-rule and pledged to continue the armed struggle ${ }^{20 .}$ Thus, many of them portray police officers as traitors ${ }^{21}$.

However, this research is designed neither to question the two parties which signed the Oslo Accords, nor to evaluate the validity of such an agreement; rather, it is to focus on the PCP mission as outlined in the Oslo II Accords. It is worth mentioning that the extent of Palestinian self-rule in accordance with the Agreement is mainly based on police success in maintaining public order. Due to the fact that the PNA has failed to promote the demilitarization of politics, the PCP was left with no choice but to interfere in politics through controlling opponents and disarming them, which in some cases resulted in bloody clashes ${ }^{22}$. Turning to the examination of the delegated authority, the PCP was established by the PLO, the sole representative of the Palestinian people, as mentioned above. This source of popular authority is the foundation of the PCP's legitimacy.

There is a stark contrast with the illegitimacy of the Israeli Police Force (IPF), which consists of Palestinian officers who appointed by the occupying authority in 1987. Both dominated almost the same territory, but in different periods. The IPF, however, was established by the authority of occupiers that have been rejected by the Palestinians since 1948. Moreover, the IPF was exercising its powers through hundreds of military Israeli orders which are totally illegal and illegitimate, not merely from the Palestinians' point of view but also from the perspective of international law ${ }^{23}$. This resulted in the overwhelming majority of the Palestinians boycotting the IPF, followed by the shutting down of the IPF. The Palestinians deemed the IPF to be part of the occupation system, regardless of the degree of professionalism that this organization had reached. This comparison indicates that the fundamental political legitimacy of a police organization is more important than its operational effectiveness: the public may tolerate some inefficiency ${ }^{24}$, but will not accept police imposed by an occupying government 25 .

The PCP gained huge popularity and sympathy during its establishment process, as this was derived from the popularity of the PLO and its chairman, Yasser Arafat ${ }^{26}$. In the eyes of the vast majority of Palestinians, the return of veterans and their leadership to the country appeared to be a victory, while the Israeli withdrawal was considered as a defeat ${ }^{27}$. Although many opponents held an extreme attitude against the Oslo Accords, they expected the PCP to be transparent and unbiased, calling police cadres their brothers ${ }^{28 .}$

However, the severe political segmentation between the two biggest political parties; Fatah and Hamas has produced volley accusations. Such accusations range from harming the country and conspiracy against each side, to involving betrayal country intentionally ${ }^{29}$ In such tense circumstances, police have been left with contested legitimacy, confusion, and inconsistent visions. Each side attempts to take advantage of police for its political purposes, but neither provides police with the resources it needs ${ }^{30}$. Police legitimacy therefore, might be seen as coextensive with loyalty to a certain faction rather than anything else. In other words, police are legitimate in the eyes of a certain faction as long as it is dominated by this faction, and vice versa.

One of the primary contributory factors in eroding police legitimacy is the politicizing of police. The police may be viewed as hostile and being polarized by the majority of Palestinians ${ }^{31}$. Thus, many people might look at police as diabolical, rejecting any cooperation with them. The public would continue to be unsatisfied regardless of the quality of police service delivered to them.

However, it is worth mentioning that investigating the PCP mission became less critical once Hamas was in the driver's seat. After the Israeli airstrikes on the Gaza Strip in 2012, Hamas signed an agreement to cease aggression against Israel, under the auspices of the US and Egyptian governments ${ }^{32}$. Many Palestinian activists may criticize Hamas based on the same argument that has been directed against the PNA by Hamas. This argument claims that the police force in the Gaza Strip is the other face of the PNA, and aims to curb army resistance in the occupied

\footnotetext{
${ }^{20}$ Turner, M. (2006). "Building Democracy in Palestine: Liberal Peace Theory and the Election of Hamas." Democratization 13(5): 739-755. Page 101. ${ }^{21}$ Kristoff, M. (2012). Policing in Palestine: Analyzing the EU Police Reform Mission in the West Bank. CIGI Security Sector Reform Issue Papers. M. Sedra. Waterloo, Canada, Centre for International Governance Innovation (CIGI). Page 36.

22 Turner, M. (2006). "Building Democracy in Palestine: Liberal Peace Theory and the Election of Hamas." Democratization 13(5): 739-755. Page 98.

${ }^{23}$ Reynolds, J. (2010). Legitimising the Illegitimate: The Israeli High Court of Justice and the Occupied Palestinian Territory. Geneva Al-Haq Organisation: 52 pages.

UNICEF (2013). Children in israeli Military detention: Observations and Recommendations. The Palestinian Territories UNICEF 22 Pages.

${ }^{24}$ MILLER, J. 2002. Civilian Oversight of Policing: Lessons from the Literature. Global Meeting on Civilian Oversight of Police, Los Angeles: Vera Institute of Justice. Page 3.

${ }^{25}$ Mulligan, S. (2004). "Questioning (the Question of) Legitimacy in IR: A Reply to Jens Steffek." European Journal of International Relations 10(3): 475484. Page 482.

${ }^{26}$ Lia, B. (2006). A police force without a state : A history of the Palestinian security forces in the West Bank and Gaza. Reading, Ithaca. Page 67.

${ }^{27}$ Frisch, H. (2010). The Palestinian Military: Between Militias and Armies, Taylor \& Francis. Page 90.

28 Weinberger, N. (1995). "The Palestinian National Security Debate." Journal of Palestine Studies 24(3): 16-30. Page 78.

${ }^{29}$ See more: Hovdenak, A. (2009). "Hamas in transition: the failure of sanctions." Democratization 16(1): 59-80. Pge 66.

Brown, N. J. (2010). "The Hamas-Fatah Conflict: Shallow but Wide." Tufts Digital Library VOL.34:2. Page 56.

30 Milton-Edwards, B. (2008). "Order Without Law? An Anatomy of Hamas Security: The Executive Force (Tanfithya)." International Peaceke eping 15(5): 663-676. Page 664.

${ }^{31}$ ICHR, T. I. C. F. H. R. (2011). The Status of Human Rights In Palestine The Seventeenth Annual Report. Page 19

ICHR, T. I. C. F. H. R. (2012). The Status of Human Rights In Palestine, Executive Summary, The Eighteenth Annual Report. Pal estine. Page 23

32 Chick, K. (2012). "Tentative ceasefire agreed between Hamas and Israel." Retrieved 11/Augest/ 2013, 2013, from www.csmonitor.com/.../Tentativeceasefire-agreed-between-Hamas-and-I...
} 
territory. Moreover, Hamas has committed the same mistakes as Fatah had during its rule, especially when it comes to the issues of human rights and individual freedoms ${ }^{33}$.

No matter whether the PCP is the main cause, or merely one of predisposing factors, it has been considered as part of the entire political system. In other words, the system is judged as a whole by the public. The police officer is a 'street corner politician" 34 . Thus, any individual accident involving the police may end up with an exaggerated reaction of the community oppressed by the governing system.

After the discussion of the PCP legitimacy as an institution, this study moves on to the evaluation of the PCP legitimacy as an organization through shedding light on police corruption and deviance.

It has been repeatedly asserted by a number of observers and monitoring organizations that corruption within Palestinian institutions (public, private, and civil society organizations) is prevalent 35 . According to several opinion polls and recent reports, Palestinian police were reported to be involved in "patronage, nepotism, and favoritism", "prejudice", "police brutality", and "waste of public funds"36.

Police corruption in Palestine can be seen as a double challenge. it encourages a culture of secrecy that creates breeding ground for political violence and gross human rights abuses. It also prevents the PCP from enforcing laws and maintaining public order. Police scandals have devastating effects on the erosion of public trust, which in turn, undermined police capacity-building and reform.

\section{b. The Consequences of Police Legitimacy}

The third theoretical issue to be addressed concerns the impacts of the erosion of police legitimacy on political platform. The loss of police legitimacy (including other security forces) would promote protest, and popular mobilization against the political system.

The activists and political opponents may not differentiate the Palestinian police officers from the occupiers; instead, they see them as the same group, and criticize the national spirit of the PNA's employees in general and the police officers in particular. Subsequently, the armed resistance against occupation would probably escalate to a civil war between those who are for and against the existence of the PNA.

Switching the negative attitudes of people towards the police will continue to be a daunting mission as long as the police are tied with politics, regardless of the improvements of its performance. The continuance of Israeli occupation and the violent invasion of the Palestinian villages and cities contribute to stimulating the Palestinians' negative image towards police officers who cannot do much to protect their people from Israeli military subversion. People may find the law enforcement at the local level irrelevant and not acceptable in coincidence with the occupation. Therefore, people's irritation, anger, and resentments might be directed intentionally or unintentionally towards the Palestinian police, Furthermore, the deteriorating of police legitimacy would probably leave the police attend to trifles and neglect the essentials. The police would be disrupted from doing its real duties as it concerns about justifying its image to the public. The urgent priority would be given therefore, to the police reputation while disclosing corruption would be of secondary importance in the organization. Police commanders may think that the confession about existing corruption will be used exaggeratedly by some of political opponents, who are keen to dismantle the organization and establish their own ${ }^{37}$.

Moreover, lack of police legitimacy may also encourage the outbreak of riots and the public rejection to comply with law. Bradford and Jackson (2011) state that lack of police legitimacy erodes the notion of state's monopoly of force, inducing people to exercise the force by themselves or create alternatives organizations ${ }^{38}$. This was the case in Palestine during the First Intifada (1987-1993), where the occupying authorities including the police were functioning with full loss of legitimacy as illustrated in Chapter Four. Accordingly, the Israeli police have been replaced partly with the heads of the clans. The influence of the clans was shaped through establishing a "Conflict Resolution Committees" (Lijan Islah), to deal with disputes that occurred at local level ${ }^{39}$.

\footnotetext{
33 Milton-Edwards, B. (2008). "Order Without Law? An Anatomy of Hamas Security: The Executive Force (Tanfithya)." International Peacekeeping 15(5): 663-676. Page 98.

${ }^{34}$ Muir, W. 1979. Police: Street corner Politicians. University of Chicago Press. USA. Page 26.

35 RAMAHI, S. 2013. Corruption in the Palestinian Authority [Online]. Middle East Monitor (MEMO) Available: http://www.middleeastmonitor.com/ [Accessedk 14 December 2013].

AMAN 2013. Opinion Poll on Corruption in Palestine for the Year 2012. Ramallah, Palestine: The Coalition for Accountability and Integrity (AMAN). Page 76

36 ICHR, T. I. C. F. H. R. (2012). The Status of Human Rights In Palestine, Executive Summary, The Eighteenth Annual Report. Palestine. Page 34 AMAN 2009. Corruption Report 2009. Ramallah, Palestine: The Coalition for Accountability and Integrity (AMAN). Page 22

AMAN 2010. Opinion poll on corruption in Palestine for the year 2009. Ramallah, Palestine: The Coalition for Accountability and Integrity (AMAN). Page 46

AMAN 2012a. Corruption Report 2011. Ramallah, Palestine: The Coalition for Accountability and Integrity (AMAN). Page 66

${ }^{37}$ Interview No (140306) with a high-rank police officer, March, 2014.

38 Bradford, B. and J. Jackson (2011). "When Trust is Lost: The British and their Police after the Tottenham Riots." books \& ideas.net: 16. Page 13.

${ }^{39}$ LANDINFO 2008. Clan Conflicts in the Palestinian Territory. Landinfo. Oslo, Norway: The Country of Origin Information Centre (Landinfo), Page 9.
} 


\section{Conclusion}

The relation between police legitimacy on the one hand, and police effectiveness on the other hand, has been examined in this research. However, defining police legitimacy is not an easy task. The legitimacy of the police can be viewed from different perspectives. For the research purpose, the existence of PCP legitimacy is to be viewed through examining whether or not, the PCP, as both institution and organisation, enjoys legitimacy in the eyes of the vast majority of the Palestinians.

\section{Research Results:}

[1] This study has argued that the PCP enjoys legitimacy in the eyes of its own people, despite some recognized deficiencies, particularly when it comes to its poor performance regarding human rights issues and the integration of political opponents into the police organization.

[2] As an organization, police legitimacy has been oscillating between hope and frustration. Binding the establishment of statehood with the success in building the PNA institutions raises the level of police legitimacy in the eyes of many Palestinians.

[3] It is worth mentioning that police legitimacy still depends to a large extent on the success of IsraeliPalestinian negotiations. In other words, if Palestinians lose faith in a peace process that should lead them to viable independent statehood, the legitimacy of the police will probably disappear with the evanescence of the Oslo Accords.

\section{Recommendations:}

[1] In order to secure the PCP's legitimacy, progress in domestic Palestinian reconciliation must take place in the future.

[2] It is highly recommended for the PCP to shift up to a higher degree of fairness, transparent, and effectiveness. Moreover, the integration of political opponents into the PCP would help to restore police legitimacy.

[3] For policing to be professional, a careful balance must be maintained between reasonable control by the executive over the police and substantial political manipulation and interference. If the police succeed in breaking down the stereotype of being ideologically aligned with the ruling political party, then police legitimacy would reach the level of "consent to policing".

\section{References:}

[1] AMAN (2009). "Corruption Report 2009". Ramallah, Palestine: The Coalition for Accountability and Integrity (AMAN).

[2] AMAN (2010). "Opinion poll on corruption in Palestine for the year 2009". Ramallah, Palestine: The Coalition for Accountability and Integrity (AMAN).

[3] AMAN (2012a). "Corruption Report 2011". Ramallah, Palestine: The Coalition for Accountability and Integrity (AMAN).

[4] AMAN (2013). "Opinion Poll on Corruption in Palestine for the Year 2012". Ramallah, Palestine: The Coalition for Accountability and Integrity (AMAN).

[5] Bradford, B. \& J. Jackson (2011). "When Trust is Lost: The British and their Police after the Tottenham Riots." books \& ideas.net: 16 .

[6] Brown, N. J. (2002). "The Palestinian Reform Agenda", UNITED STATES INSTITUTE OFPEACE. No. $48: 53$.

[7] Brown, N. J. (2010). "The Hamas-Fatah Conflict: Shallow but Wide." The Fletcher Forum of World Affairs. 34(2).

[8] Brown, N. J. (2010). "The Hamas-Fatah Conflict: Shallow but Wide." Tufts Digital Library. 34:2.

[9] Chick, K. (2012). "Tentative ceasefire agreed between Hamas and Israel." Retrieved 11/Augest/ 2013, 2013, from www.csmonitor.com/.../Tentative-ceasefire-agreed-between-Hamas-and-I...

[10] DCAF (2008). "The Security Sector Legislation of the Palestinian National Authority". Geneva: Geneva Centre for the Democratic Control of Armed Forces (DCAF).

[11] DiPasquale, D. \& E. L. Glaeser (1998). "The Los Angeles Riot and the Economics of Urban Unrest." Journal of Urban Economics. 43(1): 52-78, https://doi.org/10.1006/juec.1996.2035.

[12] Frisch, H. (2010). The Palestinian Military: Between Militias and Armies, Taylor \& Francis.

[13] Hovdenak, A. (2009). "Hamas in transition: the failure of sanctions." Democratization. 16(1): 59-80, https://doi.org/10.1080/13510340802575833.

[14] ICHR, T. I. C. F. H. R. (1997). "The Status of Human Rights In Palestine". The Thirteenth Annual Report.

[15] ICHR, T. I. C. F. H. R. (2011). "The Status of Human Rights In Palestine". The Seventeenth Annual Report.

[16] ICHR, T. I. C. F. H. R. (2012). "The Status of Human Rights In Palestine, Executive Summary". The Eighteenth Annual Report. Palestine. 
[17] Jackson, J., et al. (2012). Just Authority? : Trust in the Police in England and Wales. Hoboken, Taylor and Francis.

[18] Jansson, K. (2005). "Volume crime investigations: a review of the research literature". London Home Office. 44/05: 18.

[19] Jost, J. T. \& B. Major (2001). The Psychology of Legitimacy: Emerging Perspectives on Ideology, Justice, and Intergroup Relations. Cambridge University Press.

[20] Juergensmeyer, M. (2012). "The Legitimacy of Invading Relligious Regimes". Legality and legitimacy in global affairs. R. A. Falk, M. Juergensmeyer and V. Popovski. New York, Oxford University Press: viii, 459 p.

[21] KHALIL, A. (2007). "The Legal Framework for Palestinian Security Sector Governance". In: FRIEDRICH, R. \& LUETHOLD, A. (eds.) Entry-points to Palestinian Security Sector Reform. Geneva and Ramallah: Geneva Centre for the Democratic Control of Armed Forces.

[22] Kocken, J. (2008). " Questioning Legitimacy or Why Social Scientists Find Legitimacy Where None Exists." Social Science Research Network (SSRN), http://dx.doi.org/10.2139/ssrn.1409652.

[23] Kristoff, M. (2012). "Policing in Palestine: Analyzing the EU Police Reform Mission in the West Bank". CIGI Security Sector Reform Issue Papers. M. Sedra. Waterloo, Canada, Centre for International Governance Innovation (CIGI).

[24] Landinfo (2008). Clan conflicts in the Palestinian Territory. T. C. o. O. I. C. (Landinfo). Norway, The Country of Origin Information Centre (Landinfo) 33A: 19.

[25] Lia, B. (2006). A police force without a state : A history of the Palestinian security forces in the West Bank and Gaza. Reading, Ithaca.

[26] Luft, G. (1998). "The Palestinian Security Services: Between Police and Army." The Washington Institute. Retrieved 4/Augest/2013, 189, from http://www.washingtoninstitute.org/.

[27] Milton-Edwards, B. (1998). "Palestinian State-Building: Police and Citizens as Test of Democracy." British Journal of Middle Eastern Studies. 25(1): 95-119, https://doi.org/10.1080/13530199808705656.

[28] Milton-Edwards, B. (2007). "Hamas: Victory with Ballots and Bullets". Global Change, Peace \& Security. 19(3): 301-316, https://doi.org/10.1080/14781150701599515.

[29] Milton-Edwards, B. (2008). "Order Without Law? An Anatomy of Hamas Security: The Executive Force (Tanfithya)." International Peacekeeping. 15(5): 663-676, https://doi.org/10.1080/13533310802396236.

[30] Milton-Edwards, B. (1997). "Policing Palestinian society". Policing and Society 7(1): 19-44, https://doi.org/10.1080/10439463.1997.9964762.

[31] Muir, W. K. (1979). Police: Streetcorner Politicians. University of Chicago Press.

[32] Mulligan, S. (2004). "Questioning (the Question of) Legitimacy in IR: A Reply to Jens Steffek". European Journal of International Relations. 10(3): 475-484, https://doi.org/10.1177/1354066104045544.

[33] Myhill, A. \& Quinton. P. (2011). "It's a fair cop? Police legitimacy, public cooperation, and crime reduction". UK, NPIA (National Policing Improvement Agency): 19.

[34] Prabhat, D. (2008). "Examining Weber on Legal Legitimate Domination: A Case Study of the Opposition to the Patriot Act in the United States". Legality, legitimacy and modernity: Reconsidering Max Weber's concept of domination. R. K. Liesbeth Huppes-Cluysenaer, Oliver W. Lembcke, Reed Business: 195.

[35] RAMAHI, S. (2013). "Corruption in the Palestinian Authority [Online]". Middle East Monitor (MEM0) Available: http://www.middleeastmonitor.com/ [Accessedk 14 December 2013].

[36] Reynolds, J. (2010). Legitimising the Illegitimate: The Israeli High Court of Justice and the Occupied Palestinian Territory. Geneva Al-Haq Organisation: 52 pages.

[37] Sofaer, A. (2003). The Best Defense?: Legitimacy \& Preventive Force. California, Hoover Institution Press

[38] Turner, M. (2006). "Building Democracy in Palestine: Liberal Peace Theory and the Election of Hamas." Democratization. 13(5): 739-755, https://doi.org/10.1080/13510340601010628.

[39] Tyler, T. R. (1990). Why people obey the law. New Haven, Yale University Press.

[40] Tyler, T. \&Y, Heo (2002). "Trust in the Law: Encouraging Public Cooperation with the Police and Courts". New York, Russell Sage Foundation.

[41] Tyler, T. R. (2004). "Enhancing Police Legitimacy". Annals of the American Academy of Political and Social Science. 593: 84-99.

[42] UNICEF (2013). "Children in israeli Military detention: Observations and Recommendations". The Palestinian Territories UNICEF 22 Pages.

[43] Weinberger, N. (1995). "The Palestinian National Security Debate." Journal of Palestine Studies. 24(3): 16-30, https://doi.org/10.1525/jps.1995.24.3.00p0023j. 